\title{
The Study of Post-Earthquake Livelihood Strategy in Tandikek Padang Pariaman District
}

\author{
Sosmiarti $^{a}$, Syafruddin Karimi ${ }^{b}$, Melinda Noerc ${ }^{c}$,Werry Darta Taifur ${ }^{b}$ \\ ${ }^{a}$ Postgraduate Program, Universitas Andalas, Kampus UNAND Limau Manis, Padang, West Sumatra 25163, Indonesia \\ ${ }^{b}$ Faculty of Economics, Universitas Andalas, Kampus UNAND Limau Manis, Padang, West Sumatra 25163, Indonesia \\ ${ }^{c}$ Faculty of Agricultural, Universitas Andalas, Kampus UNAND Limau Manis, Padang, West Sumatra 25163, Indonesia
}

\section{A RTICLE INFO}

\section{Article history:}

Received 26 July 2018

Received in revised form 23 December 2018

Accepted 31 December 2018

Keywords:

Sustainable Livelihoods

Livelihood Strategy

\section{A B S T R A C T}

The objective of this study is to investigate life asset condition and household life recovery strategy after and before earthquakes in Tandikek, Padang Pariaman District. Livelihood index assessment is used to describe livelihood asset changes before and after the earthquake. A descriptive analysis is employed to describe life recovery strategy that is used by households in various level and phase of house damages. The result of the study shows that change in household life asset after the earthquake has U pattern, meaning that condition of assets for all indicators decreased during emergency and recovery phases. This condition, however, increased after recovery phase up to the present time. The condition is even better than that prior to the earthquake. This also means that all recovery efforts have successfully developed people's life assets that guarantee their life after the earthquake. The livelihood recovery strategy used by households in Tandikek to maintain and recover their livelihood varies according to the level and phase of the house damage. The households that take independent livelihood strategy, either in active or passive way, networking strategy and utilization of disaster aids from various sources appear to recover faster than those who only take one strategy.

\section{Introduction}

Disasters can affect sustainability of household livelihoods and welfare through changes in asset ownership. Efforts made by each individual to minimize vulnerability due to disasters is called survival strategy. The strategy of survival and continuing livelihoods can be grouped into three, namely: independent, active and networking strategy.

\footnotetext{
* Corresponding author

E-mail address: sos_udo@yahoo.co.id
} 
Independent strategy is a strategy that involves family members in their livelihood recovery activities both actively and passively. Active strategy is a strategy that is carried out by optimizing all the potential of the family while passive strategy is the way households minimize their expenses by getting used to frugal living. Networking strategy is utilizing the help of others in the form of social and institutional networks (Instraw, 2005; Turton, 2000; Suharto, 2009; Skouvias, 2010).

The third strategy is to utilize government assistance through community empowerment programs. All assistance received is needed to restore the conditions of livelihood and sustainability of household livelihoods. The liveliness of households in managing their remaining assets is supported by strong networks and government assistance in accordance with what is expected to accelerate the recovery of the livelihood conditions of disaster-affected households as each household has different conditions and capabilities to resist and minimize the impact of disasters (Frankenberg, et. Al, 2013; Talentino, 2007).

Research on strategies for survival in various conditions and disasters has been done. However, there is no research yet that explains the processes and stages taken by earthquake household victims in determining the strategies chosen at various levels of damage to houses (lost, severely damaged, moderate or light damaged houses). This is important because the process and stages of choice of strategies taken will minimize damage and losses caused by disaster and affect the recovery of livelihoods and the level of welfare of the households.

Thus, to fill in the gap, it is necessary to study households in the disaster area which will reveal the recovery and the sustainability of livelihoods either independently, through networking, or by utilizing government assistance. The objectives of the study are: (1) To assess the condition of household livelihood assets before and after the earthquake disaster; (2) To assess the processes and stages of the household survival strategy and recovery of livelihoods after the earthquake and utilizing government assistance.

\section{Material and Methods}

\subsection{Conceptual Framework}

Livelihoods are the efforts of households to use various resources to earn income to sustain their lives. Livelihoods are said to be sustainable if households can overcome and restore their livelihoods from the vulnerability caused by disasters by utilizing their assets, access and capabilities, and strategies that support the development of these assets.

Asset conditions at the beginning of a disaster will affect the form and size of assistance received from various parties and the choice of strategies to be taken to survive and redevelop their livelihood assets in the next phase, namely the emergency response phase, recovery, recovery and the conditions at which the research was conducted, where assistance received in any form will affect their strategies for survival, total assets and level of welfare.

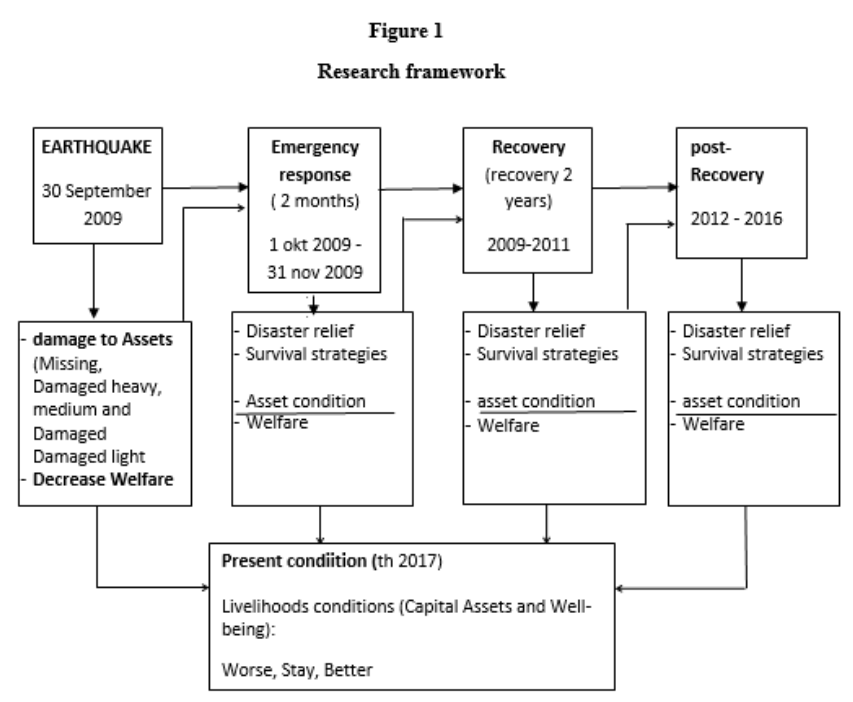

\subsection{Research Variables and Operational Definitions}

The research variables used are as follows:

a. The term 'livelihood assets' referred in this study are resources or capitals used for the sustainability of the present and future domestic life, consisting of human capital, natural capital, social capital, financial capital, and physical capital. 
b. 'Survival strategies' are way, methods, or activities used by households to obtain their income by utilizing various assets owned.

c. The 'choice of strategy' is how the strategies used by households to restore livelihoods and maintain their lives in all phases are carried out. Possible strategies taken are independent strategies, good networking or utilizing disaster assistance

\subsection{Data Analysis}

All the analysis that will be carried out after the earthquake disaster in this study is limited to 5 periods, namely the pre-disaster phase, the emergency response phase (the first 2 months after the earthquake), the recovery phase (i.e. the rehabilitation and reconstruction period of 2 years from 2010 and 2011), phase after recovery, and conditions at the time of this study.

\section{a. Livelihood Assets:}

Changes in livelihood assets before and after the earthquake were analysed by the Livelihood Index, using the following formula Cahyat (2007):

Human Capital / Physical / Natural / Financial / Social Index

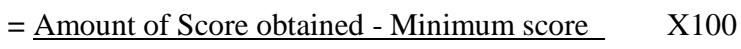

Number of maximum scores - number of Minimum scores

To obtain a livelihood index, the following formula is used:

$$
\text { livelihood index }=\frac{\mathrm{HCI}+\mathrm{PCI}+\mathrm{NCI}+\mathrm{FCI}+\mathrm{SCI}}{5}
$$

\section{b. Survival Strategy}

Descriptive analysis with the Crosstab method that displays the average value and percentage in the form of a strategy identification table was is used to analyse the process and phasing out the strategy choices made by the household to survive and continue their livelihood after the earthquake disaster.

\section{Results and Discussion}

\subsection{Condition of Household Livelihood Assets}

The condition of livelihood assets can be seen from the 5 Indicator Indices, which are human capital index, physical capital index, natural capital index, financial capital index and social capital index. The increase and decrease of these livelihood assets will influence the Livelihood Index before and after the disaster. The Livelihood Index before and after a disaster can be seen in Figure 2.

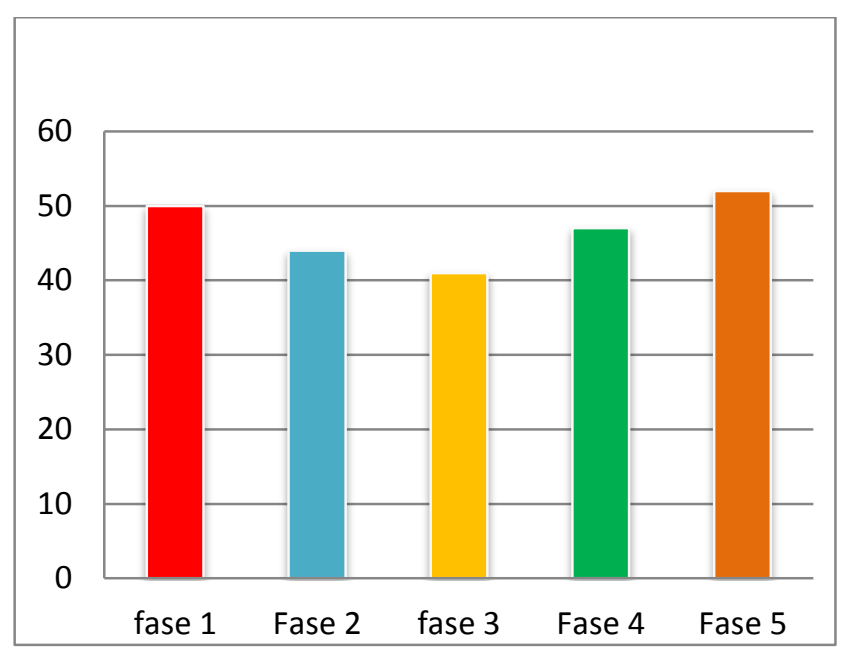

Figure 2. Livelihoods Index in all Phase

\subsection{Condition Before the Disaster.}

Before the disaster, it is obtained that the value of livelihood assets is 50 points, which belongs to medium category. The livelihood assets indicators, however, have a diverse index value. The acquisition of indices on indicators is as follows:

\section{a. Human Capital.}

The human capital index before the disaster is 40 . This figure is derived from: the last education level of the head of the family, which is graduating from elementary school; wife's last education average, which is graduating from primary education (68.9\%); average family work experience, 8 years $(72 \%)$; the head of the family generally has a permanent job (95\%); 30\% of family heads have side jobs; the 
average number of family members working is one person (80\%); generally family heads and family members have no skills (96\%); and family health conditions. Before the disaster, the average was normal $(86.5 \%)$.

\section{b. Physical Capital.}

The physical capital index before the disaster was 76 , this figure was obtained from the condition of the house, where the condition of the respondent's house before the disaster as much as $60 \%$ was permanent with an average area of $64 \mathrm{~m} 2$. Judging from the ownership status of the house, $96 \%$ of respondents occupy their own houses. For vehicle ownership, the average respondent has a vehicle of at least 1 motorbike before the disaster.

\section{c. Natural Capital}

The pre-disaster natural capital index is 48 . This figure is obtained from land ownership, where $75 \%$ of the respondents are land owners who directly process their lands for rice, coconut and cocoa, and large livestock (cows, buffaloes and goats), and poultry (chickens and ducks). And, 25\% of the respondents are not land owners but they cultivate land with a stargoan wage system.

\section{d. Financial Capital}

The financial capital index before the disaster is 31 . This result is obtained from respondents who have an average income ranging from Rp. 0 to Rp. 999,999 is $52.21 \%$; from Rp. $1,000,000$ to $1,999,999$ is $43,35 \%$, more than 2 million is $17,72 \%$.

\section{e. Social Capital}

The social capital index obtained before the earthquake was 57. This figure is derived from the participation of respondents in community organizations: $73 \%$ of respondents participated in community organizations, namely farmer groups, village arisan, majelis taklim, joint business groups, death partners and others.

\subsection{Condition after Disaster}

1) The index of livelihood after the disaster has a sharp decline in almost all indicators, a decrease in the index is 6 points, which is from 50 to 44 , in the emergency response phase. It decreases again to 41 in the recovery phase, and then increases slightly in the phase after recovery to 47 . In the current phase the condition increases quite rapidly to exceed the condition before the disaster, which is52 points.

2) The decline in the livelihood index value after the disaster implicates that there had been a decline in the number of livelihood assets owned by households, both in terms of human capital, physical capital, natural capital, financial capital, and social capital as described in the following 4 phases (Figure 3).

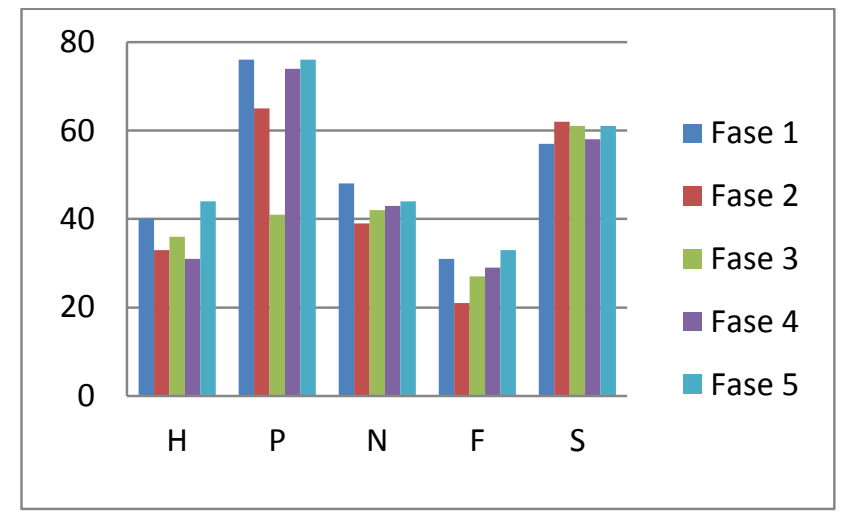

\section{Figure 3. Livelihood Indicator Index in All Phase}

3) Changes in household livelihood assets after the disaster has $U$ pattern. This means that asset conditions have decreased in the emergency response and recovery phases for all indicators, but in the recovery phase until the current conditions, all indicators have increased, even exceeds the conditions before the disaster. This means that all efforts made by households to recover have been able to develop their livelihood assets that will ensure the sustainability of livelihoods after the disaster. 


\subsection{Process and Staging of Household Strategies to Survive and Continue Their Livelihoods.}

The process and stages of survival strategies and continuing livelihoods of the disaster affected households in the study area are determined by the level of damage to the house because they will affect the choice of strategies and activities done. Activities carried out by respondents to survive and restore their livelihoods can change over time, depending on the achievements obtained in restoring livelihoods in each phase observed.

More than one activity can be carried out in each of these phases. The results of the field research show that average respondents choose four activities for each phase as a survival strategy as well as to restore their livelihood. The choice of household strategy for survival independently is as follows:

1) Back to work as usual.

2) Looking for another job

3) Looking for a side job

4) Changing types of plants

5) Selling gold

6) Selling livestock

7) Selling or mortgaging land owned

8) Involving wives and children in working

9) Making use of savings

10) Reducing expenses

11) Joining agricultural insurance

The strategy included in the networking category, which involves other people in an effort to overcome their financial difficulties to survive and continue their lives is:

1) Utilizing credit

2) Joining arisan or julojulo kampung (rotary)

3) Migrating

4) Borrowing money from parents / siblings / neighbours

5) Receiving shipments from families in the country

Strategies that utilizing government or other private sector assistances are:

1) Assistance for poor households, which is in the form of Raskin, Smart Indonesia Card (KIP), Jamkesda
/ Jamkesmas, Gas Stove, Home and cash Surgery and Family Hope Program (PKH).

2) Rolling assistance, that is an assistance provided by the district government in the form of livestock

The most frequent strategies that households do to survive in the pre-disaster phase, regardless of the level of damage to the house are: utilizing the assistance of poor households, in the form of raskin and revolving funds. Other strategies are reducing expenditure, looking for other jobs, looking for side jobs and borrowing money from parents / siblings / neighbours.

During the emergency response, the main choice made by households to survive is to return to work as usual, utilize disaster assistance, reduce household expenses, borrow money from parents / siblings / neighbours, and use savings, whether in the form of money or gold. The choice of returning to work is mostly done by respondents who did not experience damage or loss of land, including respondents whose jobs outside the agricultural sector such as drivers, traders, labourers and construction workers. Whereas for respondents whose land is lost, the strategy of surviving in the emergency response period relies more on disaster assistance, receives shipments from relatives, and borrows money from parents / siblings or neighbours.

In the recovery period, the strategies undertaken by respondents to survive were not much different from the phase taken during the emergency response period, namely: returning to work as usual, relying on disaster assistance, utilizing savings, and borrowing money from parents / relatives or neighbours.

In the post-recovery phase, the respondent's survival strategy is to use the assistance of poor households, reduce spending, find other jobs, look for side jobs, and utilize savings. Finding other jobs and side jobs was carried out by respondents who previously were farm labourers and respondents who were categorized as lost and losing land. This is because they have to move from the previous location because the area is forbidden to be occupied, so they look for new places to live and work outside the agricultural sector. The details of the choice of strategy are presented in Table 1 . 
Table 1. Percentage Survival Strategies in Different Recovery Phase

\begin{tabular}{|c|c|c|c|c|c|}
\hline $\begin{array}{c}\text { Strategies to } \\
\text { Survive }\end{array}$ & Phase 1 & Phase 2 & Phase 3 & Phase 4 & Phase 5 \\
\hline $\begin{array}{l}\text { Back to work as } \\
\text { usual }\end{array}$ & 0.00 & 17.81 & 20.27 & 100.00 & 100.00 \\
\hline $\begin{array}{l}\text { Looking for } \\
\text { another job }\end{array}$ & 11.62 & 5.99 & 6.24 & 11.30 & 11.18 \\
\hline $\begin{array}{l}\text { Looking for a side } \\
\text { job }\end{array}$ & 10.53 & 3.43 & 4.13 & 10.09 & 8.77 \\
\hline $\begin{array}{l}\text { Changing types of } \\
\text { plants }\end{array}$ & 1.45 & 1.76 & 1.09 & 2.52 & 1.89 \\
\hline Utilizing credit & 0.82 & 0.88 & 0.55 & 0.61 & 0.5 \\
\hline \begin{tabular}{|l|} 
Join arisan or Julo \\
- Julo kampung
\end{tabular} & 7.99 & 6.47 & 6.31 & 7.74 & 8.34 \\
\hline \begin{tabular}{|l} 
Joining \\
agricultural \\
insurance
\end{tabular} & 0.73 & 1.12 & 1.25 & 0.87 & 0.77 \\
\hline selling gold & 4.08 & 3.67 & 3.20 & 4.17 & 3.35 \\
\hline selling livestock & 2.54 & 1.68 & 1.95 & 2.61 & 2.24 \\
\hline \begin{tabular}{|l|} 
Selling or \\
mortgaging land \\
owned
\end{tabular} & 1.72 & 1.84 & 1.33 & 1.13 & 1.20 \\
\hline $\begin{array}{l}\text { Involving wives } \\
\text { and children in } \\
\text { working }\end{array}$ & 5.72 & 4.71 & 4.52 & 4.87 & 5.76 \\
\hline Migrating & 1.27 & 1.20 & 0.70 & 1.13 & 1.03 \\
\hline $\begin{array}{l}\text { Making use of } \\
\text { savings }\end{array}$ & 7.89 & 7.99 & 8.89 & 10.00 & 10.32 \\
\hline selling gold & 9.26 & 9.50 & 8.65 & 9.91 & 10.75 \\
\hline $\begin{array}{l}\text { Receiving } \\
\text { shipments from } \\
\text { families in the } \\
\text { country }\end{array}$ & 5.90 & 4.79 & 3.51 & 5.48 & 4.13 \\
\hline reducing expenses & 12.07 & 11.98 & 12.24 & 12.43 & 13.50 \\
\hline $\begin{array}{l}\text { Assistance for } \\
\text { poor households }\end{array}$ & 14.43 & 13.02 & 13.48 & 14.09 & 14.45 \\
\hline Rolling assistance & 2.00 & 2.16 & 1.64 & 1.04 & 1.72 \\
\hline other & 0.00 & 0.00 & 0.08 & 0.00 & 0.09 \\
\hline
\end{tabular}

The process and strategy stages that households do to survive and restore their livelihood to each category of house damage in various phases are as follow.

\section{a. Livelihood Strategy in the Lost House Category}

The survival strategy taken by most respondents in the category of lost houses before the disaster was: following arisan / julo-julo, participating in agricultural insurance, selling gold, borrowing money from parents / relatives / neighbours, and selling or mortgaging land. The above strategy is considered able to help them get out of financial difficulties in conditions without disasters. Changes in strategy per phase can be seen in Table 2 .

\section{Table 2. Livelihoods Strategy Options Category} Home Lost In Every Phase

\begin{tabular}{|c|c|c|c|c|}
\hline \multicolumn{5}{|c|}{ PHASE } \\
\hline 1 & 2 & 3 & 4 & 5 \\
\hline $\begin{array}{l}\text { Join a } \\
\text { arisan or } \\
\text { Julo - } \\
\text { Julo } \\
\text { kampung }\end{array}$ & $\begin{array}{l}\text { Migratin } \\
\mathrm{g}\end{array}$ & $\begin{array}{l}\text { Joining } \\
\text { agricultural } \\
\text { insurance }\end{array}$ & $\begin{array}{l}\text { Joining } \\
\text { agricultur } \\
\text { al } \\
\text { insurance }\end{array}$ & $\begin{array}{l}\text { selling } \\
\text { gold }\end{array}$ \\
\hline $\begin{array}{l}\text { Joining } \\
\text { agricultur } \\
\text { al } \\
\text { insurance }\end{array}$ & $\begin{array}{l}\text { selling } \\
\text { gold }\end{array}$ & $\begin{array}{l}\text { Join arisan or } \\
\text { Julo - Julo } \\
\text { kampung }\end{array}$ & $\begin{array}{l}\text { selling } \\
\text { gold }\end{array}$ & $\begin{array}{l}\text { Join } \\
\text { arisan } \\
\text { or Julo } \\
\text { - Julo } \\
\text { kampun } \\
g\end{array}$ \\
\hline $\begin{array}{l}\text { selling } \\
\text { gold }\end{array}$ & $\begin{array}{l}\text { Utilizing } \\
\text { credit }\end{array}$ & selling gold & $\begin{array}{l}\text { Join } \\
\text { arisan or } \\
\text { Julo- } \\
\text { Julo } \\
\text { kampung }\end{array}$ & $\begin{array}{l}\text { Joining } \\
\text { agricult } \\
\text { ural } \\
\text { insuran } \\
\text { ce }\end{array}$ \\
\hline $\begin{array}{l}\text { Borrowin } \\
\mathrm{g} \text { money } \\
\text { from } \\
\text { parents / } \\
\text { siblings / } \\
\text { neighbou } \\
\text { rs }\end{array}$ & $\begin{array}{l}\text { Join a } \\
\text { arisan or } \\
\text { Julo- } \\
\text { Julo } \\
\text { kampung }\end{array}$ & $\begin{array}{l}\text { Selling or } \\
\text { mortgaging } \\
\text { land owned }\end{array}$ & $\begin{array}{l}\text { Changing } \\
\text { types of } \\
\text { plants }\end{array}$ & $\begin{array}{l}\text { Changi } \\
\text { ng } \\
\text { types of } \\
\text { plants }\end{array}$ \\
\hline $\begin{array}{l}\text { Selling or } \\
\text { mortgagi } \\
\text { ng land } \\
\text { owned }\end{array}$ & $\begin{array}{l}\text { Joining } \\
\text { agricultur } \\
\text { al } \\
\text { insurance }\end{array}$ & Migrating & $\begin{array}{l}\text { Borrowin } \\
\text { g money } \\
\text { from } \\
\text { parents / } \\
\text { siblings / } \\
\text { neighbou } \\
\text { rs }\end{array}$ & $\begin{array}{l}\text { Borrowi } \\
\text { ng } \\
\text { money } \\
\text { from } \\
\text { parents } \\
\text { / } \\
\text { siblings } \\
\text { / } \\
\text { neighbo } \\
\text { urs }\end{array}$ \\
\hline
\end{tabular}

The strategy undertaken by respondents in the recovery phase, after recovery and current conditions, is to continue the strategy that has been carried out in previous phases. All phases passed by respondents to this category of lost homes generally use independent strategies and networks. Only $11 \%$ of respondents use government assistance in restoring their livelihood conditions; $95 \%$ use the above strategy.

\section{b. Strategy of Surviving in the Severely Damaged Houses Category}


The strategy to survive before the disaster by the group of households in the heavily damaged housing category was far different from the strategy used by respondents in the category of lost houses. They mostly use assistance provided by the government, both in the form of assistance for poor households and rolling assistance. The independent strategy is to involve wife and children in working and reduce expenses. Whereas the networking strategy is to receive shipments from relatives. The choice of survival strategy can be seen in Table 3 .

\section{Table 3 Strategies to Survive Category Home Heavy Damage in Every Phase}

\begin{tabular}{|l|l|l|l|l|}
\hline \multicolumn{1}{|c|}{$\mathbf{1}$} & \multicolumn{1}{|c|}{$\mathbf{2}$} & \multicolumn{1}{|c|}{$\mathbf{3}$} & \multicolumn{1}{c|}{$\mathbf{4}$} & \multicolumn{1}{|c|}{} \\
\hline $\begin{array}{l}\text { Rolling } \\
\text { assistance }\end{array}$ & $\begin{array}{l}\text { Rolling } \\
\text { assistance }\end{array}$ & $\begin{array}{l}\text { Rolling } \\
\text { assistance }\end{array}$ & $\begin{array}{l}\text { Rolling } \\
\text { assistance }\end{array}$ & $\begin{array}{l}\text { Rolling } \\
\text { assistance }\end{array}$ \\
\hline $\begin{array}{l}\text { Involving } \\
\text { wives and } \\
\text { children in } \\
\text { working }\end{array}$ & $\begin{array}{l}\text { Involving } \\
\text { wives and } \\
\text { children in } \\
\text { working }\end{array}$ & $\begin{array}{l}\text { Receiving } \\
\text { shipments } \\
\text { from } \\
\text { families in } \\
\text { the country }\end{array}$ & $\begin{array}{l}\text { Involving } \\
\text { wives and } \\
\text { children in } \\
\text { working }\end{array}$ & $\begin{array}{l}\text { Receiving } \\
\text { shipments } \\
\text { from } \\
\text { families in } \\
\text { the country }\end{array}$ \\
\hline $\begin{array}{l}\text { reducing } \\
\text { expenses }\end{array}$ & Migrating & $\begin{array}{l}\text { Involving } \\
\text { wives and } \\
\text { children in } \\
\text { working }\end{array}$ & $\begin{array}{l}\text { selling } \\
\text { livestock }\end{array}$ & $\begin{array}{l}\text { Involving } \\
\text { wives and } \\
\text { children in } \\
\text { working }\end{array}$ \\
\hline $\begin{array}{l}\text { Receiving } \\
\text { shipments } \\
\text { from } \\
\text { families in } \\
\text { the country }\end{array}$ & $\begin{array}{l}\text { Receiving } \\
\text { shipments } \\
\text { from } \\
\text { families in } \\
\text { the country }\end{array}$ & $\begin{array}{l}\text { Changing } \\
\text { types of } \\
\text { plants }\end{array}$ & $\begin{array}{l}\text { Receiving } \\
\text { shipments } \\
\text { from } \\
\text { families in } \\
\text { the country }\end{array}$ & $\begin{array}{l}\text { selling } \\
\text { cattle }\end{array}$ \\
\hline $\begin{array}{l}\text { Assistance } \\
\text { for poor } \\
\text { households }\end{array}$ & $\begin{array}{l}\text { Assistance } \\
\text { for poor } \\
\text { households }\end{array}$ & $\begin{array}{l}\text { Assistance } \\
\text { for poor } \\
\text { households }\end{array}$ & $\begin{array}{l}\text { Migrating } \\
\text { Assistance } \\
\text { for poor } \\
\text { households }\end{array}$ \\
\hline
\end{tabular}

\section{c. Survival Strategies in the Category of Moderately Damaged Houses}

The strategy of survival and restoring livelihoods in the group of damaged houses is more active than the previous group. The independent strategies chosen by respondents from groups of lost and severely damaged houses were more likely to maintain existing income sources. The strategies adopted by the respondents of the heavily damaged housing groups tended to look for other jobs outside the agricultural sector and lookedfor side jobs almost in every phase of livelihood recovery. So, it is not surprising that this group dominates the migratory strategy, and they are classified as the fastest recovering group in their livelihood, where more than $50 \%$ of this medium damaged house group can recover within one year (Table 4).

\section{Table 4 Strategies to Survive Category Houses Damaged Average in Every Phase}

\begin{tabular}{|c|c|c|c|c|}
\hline \multicolumn{5}{|c|}{ PHASE } \\
\hline 1 & 2 & 3 & 4 & 5 \\
\hline $\begin{array}{l}\text { Looking } \\
\text { for a side } \\
\text { job }\end{array}$ & $\begin{array}{l}\text { Selling or } \\
\text { mortgaging } \\
\text { land } \\
\text { owned }\end{array}$ & $\begin{array}{l}\text { Looking } \\
\text { for another } \\
\text { job }\end{array}$ & $\begin{array}{l}\text { Looking } \\
\text { for another } \\
\text { job }\end{array}$ & $\begin{array}{l}\text { Looking } \\
\text { for another } \\
\text { job }\end{array}$ \\
\hline $\begin{array}{l}\text { Looking } \\
\text { for another } \\
\text { job }\end{array}$ & $\begin{array}{l}\text { Looking } \\
\text { for another } \\
\text { job }\end{array}$ & $\begin{array}{l}\text { Looking } \\
\text { for another } \\
\text { job }\end{array}$ & $\begin{array}{l}\text { Looking } \\
\text { for a side } \\
\text { job }\end{array}$ & $\begin{array}{l}\text { Looking } \\
\text { for a side } \\
\text { job }\end{array}$ \\
\hline $\begin{array}{l}\text { Utilizing } \\
\text { credit }\end{array}$ & $\begin{array}{l}\text { Back to } \\
\text { work as } \\
\text { usual }\end{array}$ & $\begin{array}{l}\text { Utilizing } \\
\text { savings }\end{array}$ & $\begin{array}{l}\text { Changing } \\
\text { types of } \\
\text { plants }\end{array}$ & $\begin{array}{l}\text { Utilizing } \\
\text { credit }\end{array}$ \\
\hline $\begin{array}{l}\text { Making } \\
\text { use of } \\
\text { savings }\end{array}$ & $\begin{array}{l}\text { Making } \\
\text { use of } \\
\text { savings }\end{array}$ & $\begin{array}{l}\text { Borrowing } \\
\text { money } \\
\text { from } \\
\text { parents / } \\
\text { siblings / } \\
\text { neighbours }\end{array}$ & $\begin{array}{l}\text { Joining } \\
\text { agricultural } \\
\text { insurance }\end{array}$ & $\begin{array}{l}\text { Making } \\
\text { use of } \\
\text { savings }\end{array}$ \\
\hline $\begin{array}{l}\text { Borrowing } \\
\text { money } \\
\text { from } \\
\text { parents / } \\
\text { siblings / } \\
\text { neighbours }\end{array}$ & Migrating & $\begin{array}{l}\text { Utilizing } \\
\text { credit }\end{array}$ & $\begin{array}{l}\text { Utilizing } \\
\text { credit }\end{array}$ & $\begin{array}{l}\text { Borrowing } \\
\text { money } \\
\text { from } \\
\text { parents / } \\
\text { siblings / } \\
\text { neighbours }\end{array}$ \\
\hline
\end{tabular}

\section{d. Survival Strategy in The Category of Lightly Damaged Houses}

In the group of lightly damaged houses, the survival strategies before and after the disaster for the independent strategy category were mostly to sustain existing livelihoods. This can be seen in all phases of recovery. In the pre-disaster phase, the respondents took part in agricultural insurance to minimize the risk of crop failure. The next strategy is to utilize existing credit institutions in banks and non-bank financial institution. If these two stages are not successful, they will choose to migrate, sell or mortgage their land, or use savings, both in the form of money and gold. Changes to the choice of group strategy can be observed in Table 5. 
Table 5. Strategy to Survive Category Houses Damaged Light In Every Phase

\begin{tabular}{|c|c|c|c|c|}
\hline \multicolumn{5}{|c|}{ PHASE } \\
\hline 1 & 2 & 3 & 4 & 5 \\
\hline $\begin{array}{l}\text { Joining } \\
\text { agricultural } \\
\text { insurance }\end{array}$ & $\begin{array}{l}\text { Joining } \\
\text { agricultura } \\
1 \text { insurance }\end{array}$ & Migrating & Migrating & $\begin{array}{l}\text { Joining } \\
\text { agricultural } \\
\text { insurance }\end{array}$ \\
\hline $\begin{array}{l}\text { Utilizing } \\
\text { credit }\end{array}$ & $\begin{array}{l}\text { selling } \\
\text { livestock }\end{array}$ & $\begin{array}{l}\text { Join } \\
\text { arisan or } \\
\text { Julo- } \\
\text { Julo } \\
\text { kampung }\end{array}$ & $\begin{array}{l}\text { Join } \\
\text { arisan or } \\
\text { Julo- } \\
\text { Julo } \\
\text { kampung }\end{array}$ & Migrating \\
\hline Migrating & $\begin{array}{l}\text { Participate } \\
\text { gathering / } \\
\text { Julo-Julo }\end{array}$ & $\begin{array}{l}\text { selling } \\
\text { gold }\end{array}$ & $\begin{array}{l}\text { selling } \\
\text { gold }\end{array}$ & $\begin{array}{l}\text { Join arisan } \\
\text { or Julo- } \\
\text { Julo } \\
\text { kampung }\end{array}$ \\
\hline $\begin{array}{l}\text { Selling or } \\
\text { mortgaging } \\
\text { land owned }\end{array}$ & $\begin{array}{l}\text { reducing } \\
\text { expenses }\end{array}$ & $\begin{array}{l}\text { reducing } \\
\text { expenses }\end{array}$ & $\begin{array}{l}\text { reducing } \\
\text { expenses }\end{array}$ & selling gold \\
\hline $\begin{array}{l}\text { Making use } \\
\text { of savings }\end{array}$ & $\begin{array}{l}\text { selling } \\
\text { gold }\end{array}$ & $\begin{array}{l}\text { Assistanc } \\
\text { e for poor } \\
\text { househol } \\
\text { ds }\end{array}$ & $\begin{array}{l}\text { Assistanc } \\
\text { e for poor } \\
\text { househol } \\
\text { ds }\end{array}$ & $\begin{array}{l}\text { Assistance } \\
\text { for poor } \\
\text { households }\end{array}$ \\
\hline
\end{tabular}

\section{e. Strategies for Surviving the House Category Not Damaged.}

The strategy of surviving the non-damaged house category is more active and full of creativity in developing its livelihood assets compared to the previous four groups. The strategy taken can synergize the three existing survival strategies, namely being independent with full creativity, utilizing the opportunities that exist by maximizing the assistance provided by the government, and using networks to develop assets for their livelihoods. This can be seen in the choice of survival strategies in the pre-disaster phase, namely exchanging plant types, utilizing rolling assistance, looking for other jobs, selling / mortgaging land, and looking for side jobs. Comparison of options for this group strategy can be seen in Table 6 .

Households that are able to combine independent survival strategies both actively and passively with networking strategies and utilize disaster assistance from various parties have been shown to recover faster from households that only rely on one strategy because the recovery rate of a household from vulnerability due to disasters will varies, depending on asset factors, knowledge, duration of disasters, character of disasters, extent of damage and losses, regional characteristics and socio-economic conditions and the influence of external factors (Noviani, 2013; Chamber and Conway, 1992) and problems maintaining survival will vary according to the degree and goals to be achieved by each individual.

\section{Table 6. Strategies to Survive Category Home Undamaged In Every Phase}

\begin{tabular}{|c|c|c|c|c|}
\hline \multicolumn{5}{|c|}{ PHASE } \\
\hline 1 & 2 & 3 & 4 & 5 \\
\hline $\begin{array}{l}\text { Changing } \\
\text { types of } \\
\text { plants }\end{array}$ & $\begin{array}{l}\text { Changing } \\
\text { types of } \\
\text { plants }\end{array}$ & $\begin{array}{l}\text { Changin } \\
\mathrm{g} \text { types } \\
\text { of plants }\end{array}$ & $\begin{array}{l}\text { Utilizing } \\
\text { credit }\end{array}$ & $\begin{array}{l}\text { Utilizing } \\
\text { credit }\end{array}$ \\
\hline $\begin{array}{l}\text { Rolling } \\
\text { assistance }\end{array}$ & $\begin{array}{l}\text { Utilizing } \\
\text { credit }\end{array}$ & $\begin{array}{l}\text { Looking } \\
\text { for } \\
\text { another } \\
\text { job }\end{array}$ & $\begin{array}{l}\text { Selling or } \\
\text { mortgagi } \\
\text { ng land } \\
\text { owned / }\end{array}$ & $\begin{array}{l}\text { Changin } \\
\mathrm{g} \text { types } \\
\text { of plants }\end{array}$ \\
\hline $\begin{array}{l}\text { Looking } \\
\text { for another } \\
\text { job }\end{array}$ & $\begin{array}{l}\text { Looking } \\
\text { for } \\
\text { another } \\
\text { job }\end{array}$ & $\begin{array}{l}\text { Joining } \\
\text { agricultu } \\
\text { ral } \\
\text { insuranc } \\
\text { e }\end{array}$ & $\begin{array}{l}\text { Changing } \\
\text { types of } \\
\text { plants }\end{array}$ & $\begin{array}{l}\text { Looking } \\
\text { for a } \\
\text { side job }\end{array}$ \\
\hline $\begin{array}{l}\text { Selling or } \\
\text { mortgagin } \\
\text { g land } \\
\text { owned }\end{array}$ & $\begin{array}{l}\text { Back to } \\
\text { work as } \\
\text { usual }\end{array}$ & $\begin{array}{l}\text { Looking } \\
\text { for a } \\
\text { side job }\end{array}$ & $\begin{array}{l}\text { Looking } \\
\text { for } \\
\text { another } \\
\text { job }\end{array}$ & $\begin{array}{l}\text { Looking } \\
\text { for } \\
\text { another } \\
\text { job }\end{array}$ \\
\hline $\begin{array}{l}\text { Looking } \\
\text { for a side } \\
\text { job }\end{array}$ & $\begin{array}{l}\text { Selling or } \\
\text { mortgagin } \\
\text { g land } \\
\text { owned }\end{array}$ & $\begin{array}{l}\text { Back to } \\
\text { work as } \\
\text { usual }\end{array}$ & $\begin{array}{l}\text { Looking } \\
\text { for a side } \\
\text { job }\end{array}$ & $\begin{array}{l}\text { selling } \\
\text { gold }\end{array}$ \\
\hline
\end{tabular}

\section{Conclusion}

a. Changes in household livelihood assets after the disaster show a U pattern. This means that asset conditions have decreased in the emergency response phase and recovery for all indicators has increased again, even exceeding the conditions before the disaster, in the phase after recove to the current conditions. This shows that all efforts by households to recover have been able to develop their livelihood assets that will ensure the sustainability of livelihoods after a disaster,

b. Livelihood recovery strategies carried out by households in Nagari Tandikek to survive and restore their livelihoods have been shown to differ according to the level of damage to houses and phases. Households that are able to combine independent survival strategies, both active and passive, with networking strategies and utilizing disaster assistance from various parties, are proven to recover faster than households that only rely on one strategy. 


\section{References}

Baiquni, M. 2007. Livelihood Strategies in Times of Crisis. Idial Media, Yogyakarta.

Bekele, Adugna. E, 2008. Livelihood Strategies And Food Security Inwolayta, Southern Ethiopia: The Case Of Bolososore District, Thesis Submitted to the Department of Rural Development and Agricultural Extension, Schoolof Haramaya University Graduate Studies

Cahyat, A., Gönner, C. and Haug, M. 2007 Assessing Poverty and Household Welfare: A Guide denganContoh of Kutai Barat, Indonesia. CIFOR, Bogor, Indonesia. 121p.

Chambers, Robert and Gordon Conway (1991), Sustainable Rural Livelihoods: Practical Concepts for the 21st Century, Discussion Paper 296, Brighton: Institute of Development Studies

DFID. 1999. Sustainable Livelihoods Guidance Sheets. For the Department For International Development. London

DFID (2001). Sustainable livelihoods Guidance Sheets. Department for International Development,http://www.livelihoods.org/

Ellis, F. (2000). Rural Livelihoods and Diversity in Developing Countries. Oxford: Oxford University Press.

Frankenberg, E., C. Sumantri, and D. Thomas. 2013. "The Evolution of Well-Being in the Aftermath of a Disaster: Evidence from Aceh and North Sumatra. Submitted for presentation at the Conference "The Demography of Disasters: Implications for Future Policy on Development and Resilience." The Australian Demographic and Social Research Institute

Hidayati, D. 2012. "Striving to Reduce Disaster Risk: Vulnerable Communities with Low Levels of Preparedness in Indonesia", Journal of Disaster Research, 7 (1): 75-82.

INSTRAW. 2005. "Gender, Remittances and Development: Research Gaps and Future Priorities" Presentation to Conference of Women Leaders, September 27th, 2005, Haifa, Israel

Khan, Mohammad Asif, 2008. Livelihood Strategies and Employment Structure in Northwest
Pakistan. Dissertation, University of Gottingen, Germany

Mavunduse, D., M. Nandango, S. Saadi, and E. De Leon. 2000. Participatory Vulnerability Analysis: A Step-By-Step Guide For Field Staff. Emegencies Program. Action Aids. UK.

Nurhadi, 2015, Identification of Vulnerable Household Earthquake-In Area Bantul in Yogyakarta, Re Sociologyflektif, Volume 9, No. 2, April 2015.

Olshansky, R. and Chang, S., 2009. Planning for Disaster Recovery: Emerging Research Needs And Challenge Progress in Planning, 72: 200209.

Skoufias, E., Lunde, T., \& Patrinos, H. (2010). Social Networks Among Indigenous Peoples in Mexico. Latin American Research Review, 45 (2).

Talentino, Amado, S. (2007). The Challenges of Tsunami Disaster Response Planning and Management. International Review for Environmental Strategies, 7 (1), 1476-154.

Turton, Cathryn, 2000. Enhancing Livelihoods Through Participatory Watershed Development In India. Overseas Development Institute Portland House Stag Place London SW1E 5DP UK 